\title{
Jean Rohou, Le Classicisme (1660-1700)
}

\section{Monica Pavesio}

\section{(2) OpenEdition}

\section{Journals}

\section{Edizione digitale}

URL: http://journals.openedition.org/studifrancesi/27527

DOI: 10.4000/studifrancesi.27527

ISSN: 2427-5856

\section{Editore}

Rosenberg \& Sellier

\section{Edizione cartacea}

Data di pubblicazione: 31 décembre 2006

Paginazione: 598

ISSN: 0039-2944

\section{Notizia bibliografica digitale}

Monica Pavesio, « Jean Rohou, Le Classicisme (1660-1700) », Studi Francesi [Online], 150 (L | III) | 2006 , online dal 30 novembre 2015, consultato il 08 novembre 2020. URL : http://journals.openedition.org/ studifrancesi/27527 ; DOI : https://doi.org/10.4000/studifrancesi.27527

\section{Questo documento è stato generato automaticamente il 8 novembre 2020.}

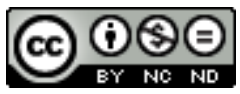

Studi Francesi è distribuita con Licenza Creative Commons Attribuzione - Non commerciale - Non opere derivate 4.0 Internazionale. 


\title{
Jean Rohou, Le Classicisme (1660-1700)
}

\author{
Monica Pavesio
}

\section{NOTIZIA}

JEAN ROHOU, Le Classicisme (1660-1700), Collection «Didact français», Rennes, Presses Universitaires, 2004, pp. 164.

1 Una prima edizione di questo utile manuale di J. Rohou, destinato agli studenti del primo ciclo di studi letterari, è uscita nel 1996, nella collezione "Les Fondamentaux" dell'Edizioni Hachette.

Le Presses Universitaires de Rennes hanno deciso di ripubblicare otto anni dopo questo interessante volume sul Classicismo che non descrive gli autori e le opere, ma propone una visione globale dei principi di un'epoca letteraria eccezionale.

Dopo una prima definizione del periodo classico e del termine "classicismo", l'autore ne rintraccia i modelli, la genesi, le motivazioni e l'evoluzione durante il regno di Luigi XIV. Dedica poi un lungo capitolo all'antropologia classica, ossia alla visione pessimista di un uomo egocentrico che cerca in vano di colmare la propria avidità, ed espone le ragioni di questo pessimismo, che si riflette in un'estetica di regolarità e di elegante nobiltà. Studia infine i principi classici applicati ai principali generi letterari: teatro, poesia e prosa, precisandone la poetica.

4 I principali volumi dedicati alla storia letteraria del XVII secolo e al classicismo, le antologie e gli scritti teorici sono raccolti in un'essenziale, ma utile bibliografia conclusiva. 